\title{
Feeding Habits of the Green Jack (Caranx caballus Günther, 1868) on the Coast of Manzanillo, Colima, México
}

\author{
Mirella Saucedo-Lozano ${ }^{1}$, Iván H. Bernal-Ornelas ${ }^{1}$, Elaine Espino-Barr ${ }^{*}, 2$, Arturo Garcia-Boa ${ }^{2}$, \\ Esther G. Cabral-Solís ${ }^{2}$ and Marcos Puente-Gómez ${ }^{2}$ \\ ${ }^{1}$ Universidad de Guadalajara, Centro Universitario de la Costa Sur Departamento de Estudios para el Desarrollo \\ Sustentable de Zonas Costeras, Gómez Farías No. 82, San Patricio, Melaque, Jalisco, C.P. 48980, México \\ ${ }^{2}$ CRIP-Manzanillo, INAPESCA, Playa Ventanas s/n Manzanillo, Colima, 28200, México
}

\begin{abstract}
To increase the knowledge on the biology and the ecology of Caranx caballus (green jack), a dietary analysis was carried out. Stomachs of 271 specimens from the commercial catches of the artisanal fishery along the coasts of Manzanillo, Colima, México from December 2000 to December 2001 were analyzed. Prey items in the stomach contents were identified, counted and weighed, the percentage frequency of occurrence, percentage by number and percentage by weight were calculated. We also determined indices of relative importance, diversity of trophic spectra and feeding. Forty two dietary components from five taxa were apparent: fishes, crustaceans, mollusks, cnidarians and chaetognaths. Percentage weight and volume did not vary throughout the year, and showed a distinct preference for fishes, whereas the numeric index showed a preference for crustaceans followed by fishes, chaetognaths and cnidarians. There was no difference between the diets of females and males. Feeding between green jack size groups changed with development: in terms of weight percentage, small fish fed on crustaceans, medium and large jacks fed on fishes, crustaceans and cnidarians.
\end{abstract}

Keywords: Dietary index, diet spectrum, fish, gender, length, trophic niche.

\section{INTRODUCTION}

Fisheries, especially of the artisanal type are basic for the local economy in the northern region of Colima, México. Caranx caballus Günther, 1868 belongs to the Carangidae family and, although it is not a commercially important species because of its dark meat, it is fished very extensively and consumed locally, as a cheap popular option. During 2000, 60t of C. caballus were landed (Fishery Statistics in Colima). In spite of its high populations, very little is known of its biology and ecology [1]. This paper describes the range of sizes of C. caballus fished with gillnets in the artisanal fishery of a tropical area.

Studies on feeding generate information fundamental to understanding the dynamics of the ecological interactions between species. Species within the Carangidae are demersal or pelagic and typically gregarious, and live on the continental shelf, generally near the coast but also in water deeper than $100 \mathrm{~m}[2,3]$.

Carangids have been divided into three groups according to their food preference: piscivores (e.g. species of Caranx and Seriola), planktivores (e.g. Decapterus and Selar) and mollusk-feeders (Trachinotus) (Randall, 1967 in [4]); C. caballus belongs to the first group. Studies have shown that young individuals of $C$. rubber feed on planktonic organisms whereas adults feed on fishes [5]. These authors [5] also showed that $C$. bartholomaei feeds primarily on fishes

*Address correspondence to this author at the CRIP-Manzanillo, INAPESCA, Playa Ventanas s/n Manzanillo, Colima, 28200, México; Tel: (01)3143323750; Fax: (01)31 433237 51; E-mail: elespino@gmail.com belonging to the Labridae and Scaridae families. Others [6] have described the feeding of C. hippos and, similarly, found its diet to comprise mostly fishes. Again, observations of Oligoplites saurus and O. palometa have shown that the main dietary components were fishes and crustaceans [7]. $C$. caballus feeds mainly on fishes (generally species exhibiting silver-plated colour), shrimp, crabs and other invertebrates $[8,9]$.

To increase knowledge of the biology and ecology of $C$. caballus, we analyzed the composition and quantity of this species' diet over a full year, paying particular attention to variation according to fish length and sex. Two hypotheses were studied: diet does not change from juvenile to adulthood, and diet changes throughout the year, depending on presence of prey.

\section{METHODS}

The study area is located on the Mexican Pacific, to the north of Michoacán and the south of Jalisco state, $19^{\circ} 03^{\prime} \mathrm{N}$ and $104^{\circ} 19^{\prime} \mathrm{W}$. Its continental platform is $1,340 \mathrm{~km}^{2}$ [10], in which the isobath of 200 fathoms $(366 \mathrm{~m})$ is at the northern part $9 \mathrm{~km}$ from of the coast and $24 \mathrm{~km}$ south. The coast is approximately $157 \mathrm{~km}$ long; characterized by a succession of steep rocky coasts and flat sandy beaches.

Monthly samplings from December 1999 to December 2000 were of the commercial captures of the artisanal fishery of the coast of Colima. Fish were captured mainly with gill nets, coastal seine and pound nets. Of each organism total length (from the mouth to the end of the caudal fin) was measured with individual icthyometer $(1$ millimeter of 
precision). Individual weight was determined with a semianalytical balance ( $0.1 \mathrm{~g}$ of precision).

The stomach of each organism was obtained and conserved in $10 \%$ formaldehyde, properly labeled for later analysis.

In the lab, contents of each stomach was drained in a Petri dish and analyzed with stereoscopic microscope. Each prey was identified to the lowest possible taxonomic level, using specialized keys for the different groups: [11-16] for invertebrates; [2, 3, 17] for fish; for plankton [18] and [19] for icthyoplankton, and the help of specialists in each taxonomic group. Each prey was counted, weight and its volume measured to calculate the indices:

Percentage by number (numeric index $\% \mathrm{~N}$ ) [20]: total number of individuals of a group, expressed as percentage of the total individuals.

Percentage by weight (Gravimetric index \%W) [21]: total weight of individuals in a group expressed as percentage of the total weight.

Due to the difference in length of the prey the volumetric Index $(\% \mathrm{~V})[20]$ was also used: Total percentage volume of displaced water of each consumed organism was measured, in a graduated test tube.

Percentage frequency of occurrence (FA) [22]: as total number of stomachs, in which each type of prey was found, expressed in appearance percentage of the total number of stomachs.

The Index of Relative Importance (IRI) was calculated with the mentioned indices, expressed in percentage, taking into consideration the importance of each prey individually [20]. It is outlined graphically in rectangular form, with the base representing the frequency of appearance (FA) and the height the sum of numerical $(\mathrm{N})$ and gravimetric (W) indices.

$$
\begin{gathered}
I R I_{W}=(W+N) * F \\
I R I_{V}=(V+N) * F
\end{gathered}
$$

Where: $\mathrm{W}=$ percentage of weight, $\mathrm{V}=$ percentage of volume, $\mathrm{N}=$ number of organisms percentage and $\mathrm{F}=$ appearance frequency percentage.

Total length was used to determine length classes of $C$. caballus and the number of classes was calculated with Sturges' formula [23]:

$$
K=1+3.322\left(\log _{10} n\right)
$$

Where: $\mathrm{K}=$ number of class intervals, $\mathrm{n}=$ number of total data.

After determining the number of class intervals, its amplitude was calculated with the formula described in [23]:

$$
A=\frac{R}{K}
$$

Where: $\mathrm{A}=$ interval amplitude, $\mathrm{R}=$ maximum value minus minimum value and $\mathrm{K}=$ interval number.
Trophic spectrum amplitude (niche breadth) was evaluated with the diversity of the feeding spectrum [24]. Data of weight and number were used for this index, expressed in percentage and standardized for maximum amplitude [25] using a scale 0 to 1 :

$$
\begin{gathered}
B=\frac{1}{\sum_{i=1}^{n} P j^{2}} \\
B_{a}=\frac{B-1}{n-1}
\end{gathered}
$$

Where: $\mathrm{B}=$ Levin's measurement of the diet spectrum; $\mathrm{Ba}=$ standardized Levins' measurement; $\mathrm{Pj}=$ proportion with which every prey category contributes to the diet and $n=$ total number of feeding items. Values of $\mathrm{Ba}$ include a scale 0 to 1 ; it is the maximum value when species consume different items in the same proportion (wide trophic niche) and minimum when they feed mainly in one type of food (maximum specialization).

The most important group of prey in the diet of $C$. caballus as well as those consumed accidentally, were calculated with the Alimentary Index (AI) modified [26]:

$$
A I=\frac{\% F * \% W(\% A)}{100}
$$

With feeding preferences $(\% \mathrm{~F})$ and relative importance of the prey, in weight $(\% \mathrm{~W})$ or area $(\% \mathrm{~A})$, AI brings together feeding items in a function that allows the preferred food from those of low frequency be distinguish [21]. Values of AI vary from 0 to $100 \%$ and are categorized according to their relative importance as follows: 1) preferential food (AI $>50), 2)$ secondary food $(25<\mathrm{AI}<50), 3)$ frequent food $(10$ $<\mathrm{AI}<25)$ and accidental food $(\mathrm{AI}<10)$.

\section{RESULTS}

From commercial catches in Manzanillo, Colima, México, 1,084 individuals were caught and 582 stomachs analyzed, of which 311 (53\%) were empty and 271 (47\%) with contents. January, September and November 2001 were the months with more abundance of $C$. caballus. The largest length was $57 \mathrm{~cm}$ and the smallest $21.5 \mathrm{~cm}$, average length was $30.77 \mathrm{~cm} \pm 6.98$ standard deviation. All specimens under $22 \mathrm{~cm}$ were considered juveniles because its gender could not be visually determined [27], from 23 to $30 \mathrm{~cm}$ they were considered preadults their sex could be determined, but they were all immature; from $31 \mathrm{~cm}$ on, the organisms were considered adults.

Stomach content of C. caballus had 42 feeding items of 5 higher taxa (Table 1): fish, crustaceans, mollusks, cnidarians and chaetognata. Analysis included two extra groups: "Crustacean larvae" due to its difference with the other Crustaceans and "Organic matter", elements that could not be identified.

Based on percentage in number $(\% \mathrm{~N})$, monthly's most important feeding component changed throughout the year: fish in December $2000(100 \%)$; crustaceans in March 
$(97.30 \%)$; cnidarians $(66.66 \%)$ in January, and in July the most abundant item were crustacean larvae (100\%) (Fig. 1).
Most months appeared to have crustacean as an important item in the diet.

Table 1. List of Prey Species (items) Found in Stomach Contents of Caranx caballus

\begin{tabular}{|c|c|}
\hline Fishes & Trachysalambria brevisuturae \\
\hline Family Engraulidae & Trachysalambria sp. \\
\hline Family Clupeidae & Portunus xantusi \\
\hline Ophisthonema libertate & Portunus sp. \\
\hline Ophisthonema sp. & Pleuroncodes planipes \\
\hline Family Serranidae & Stomatopod larvae \\
\hline Family Congridae & Anomura larvae \\
\hline Caranx sp. & Brachyura larvae \\
\hline Fish larvae & Portunid larvae \\
\hline Pieces of fish & Megalops larvae \\
\hline CRUSTACEANS & Mysis larvae \\
\hline Brachyura & Crab Zoea larvae \\
\hline Euphausiacea & Unidentified Crustacea \\
\hline Ostracoda & MOLLUSKS \\
\hline Caridea & Family Naticidae \\
\hline Cladocera & Nassarius gallegosi \\
\hline Copepoda & Loliolopsis diomedae \\
\hline Calanoida Copepoda & Rests of mollusks \\
\hline Centropagues sp. & CNIDARIANS \\
\hline Solenocera sp. & Siphonophora \\
\hline Stomatopoda juvenile & CHAETOGNATHA (unidentified) \\
\hline Rimapenaeus fascina & Organic matter \\
\hline Rimapenaeus sp. & \\
\hline
\end{tabular}
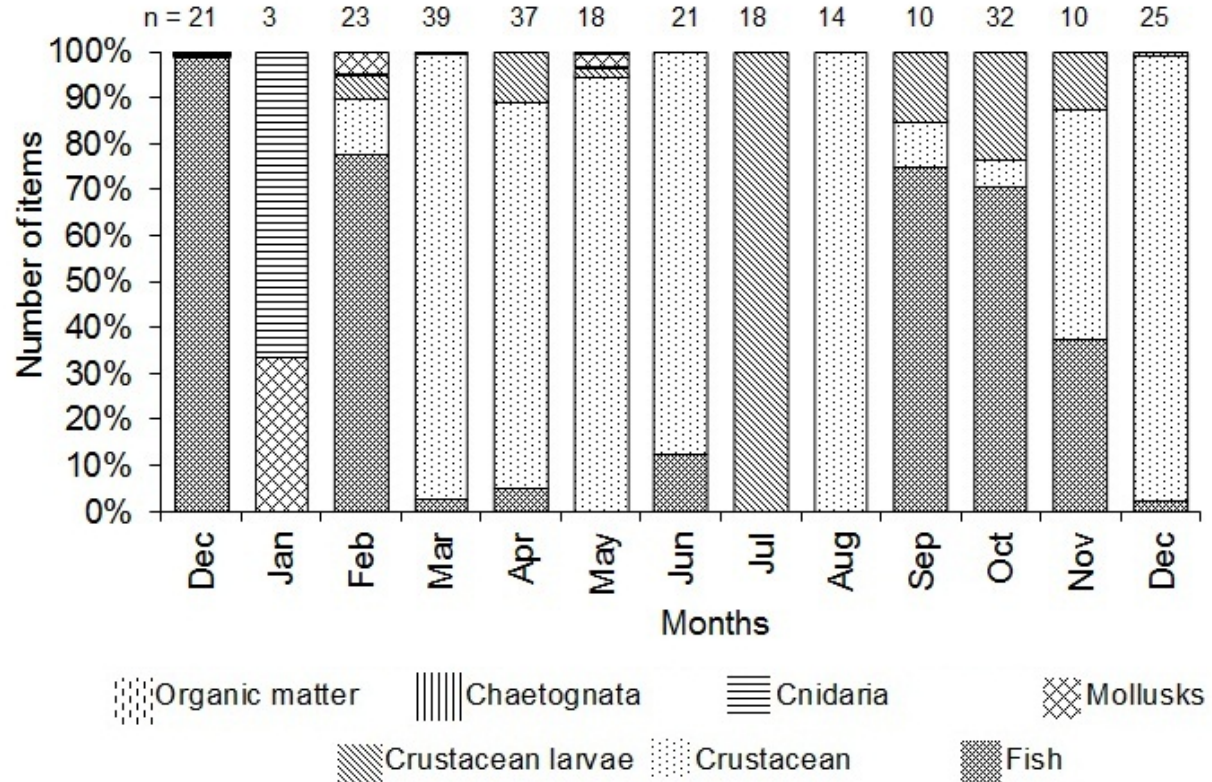

Fig. (1). Numeric index $(\% \mathrm{~N})$ of the prey groups of Caranx caballus during one year. 


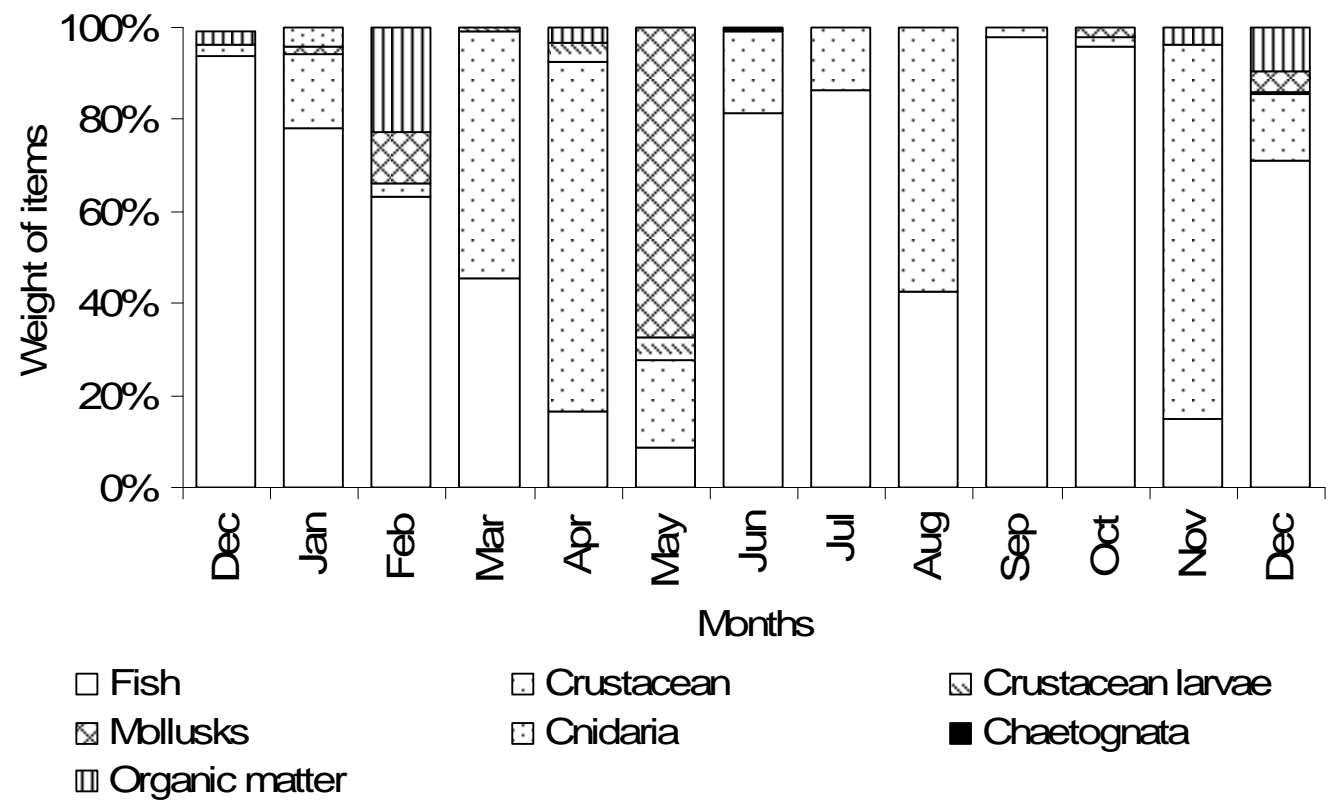

Fig. (2). Gravimetric index (\%W) of the prey groups of Caranx caballus during one year.

Feeding components as percent weight $(\% \mathrm{~W})$ indicated fish as preference for $C$. caballus throughout the year, mainly in September (97.93\%) and October (96.01\%). There was also an important consumption of crustaceans in April $(76.20 \%)$ and November (81.36\%); and of mollusks (67.17\%) in May (Fig. 2).

The volumetric index $(\% \mathrm{~V})$ was very similar to the gravimetric in the preference to fish during almost the year round, and probably a periodic behavior with maximum from December to February and from June to October.
Crustaceans were especially important in March (52.52\%), April (81.66\%) and August (65.15\%). There was little preference for mollusks in most months except May (69.34\%). Preference for crustacean larvae were observed in November (51.76\%) (Fig. 3).

The Index of Relative Importance calculation in weight $\left(I_{\mathrm{R}} \mathrm{I}_{\mathrm{W}}\right)$ showed greater consumption of fish from December to February, and from June to October; crustaceans were the group with greater percentage during March (58.4\%), April (92.2\%), August $(76.2 \%)$ and November $(96.5 \%)$ and

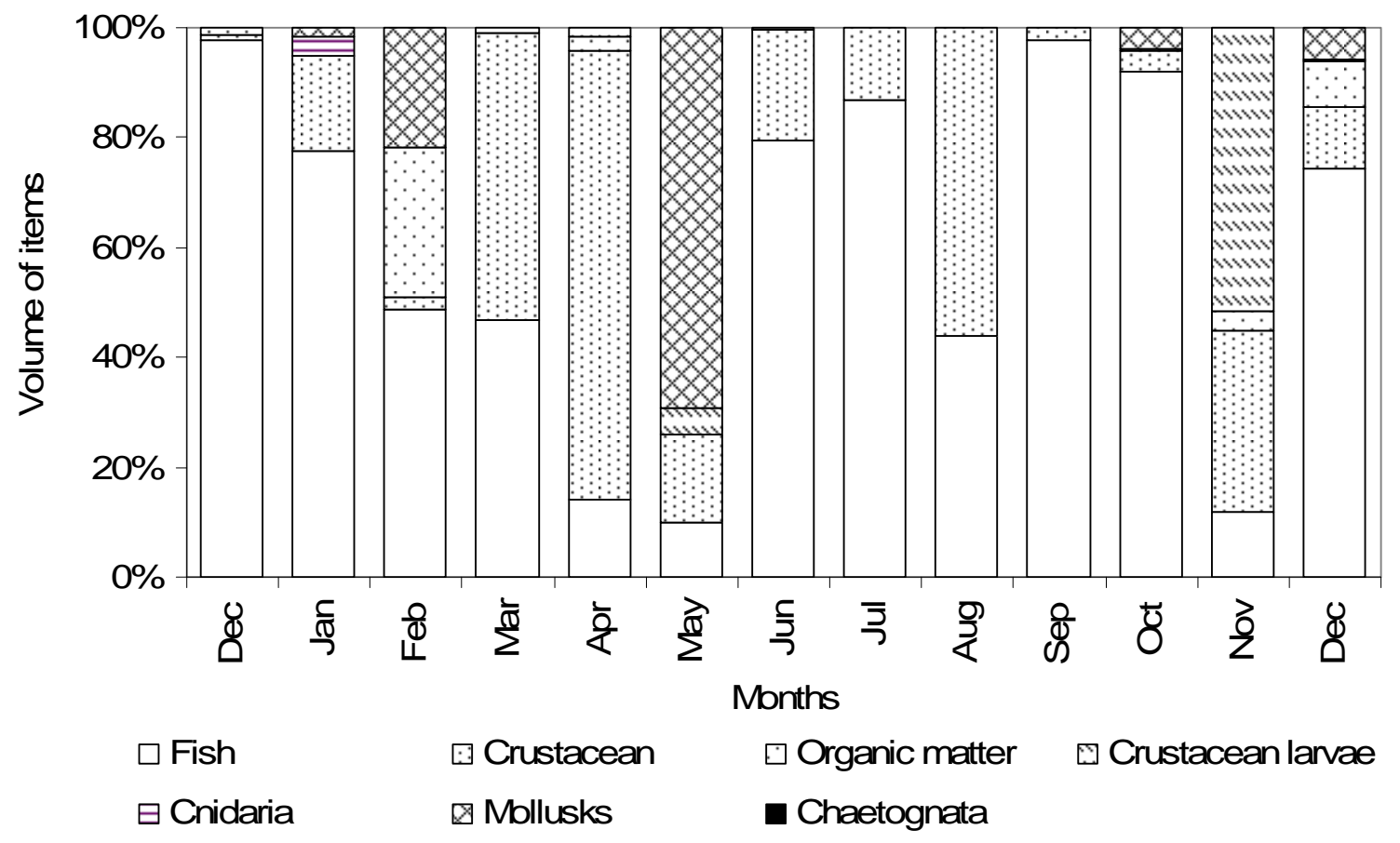

Fig. (3). Volumetric index $(\% \mathrm{~V})$ of the prey groups of Caranx caballus during one year. 

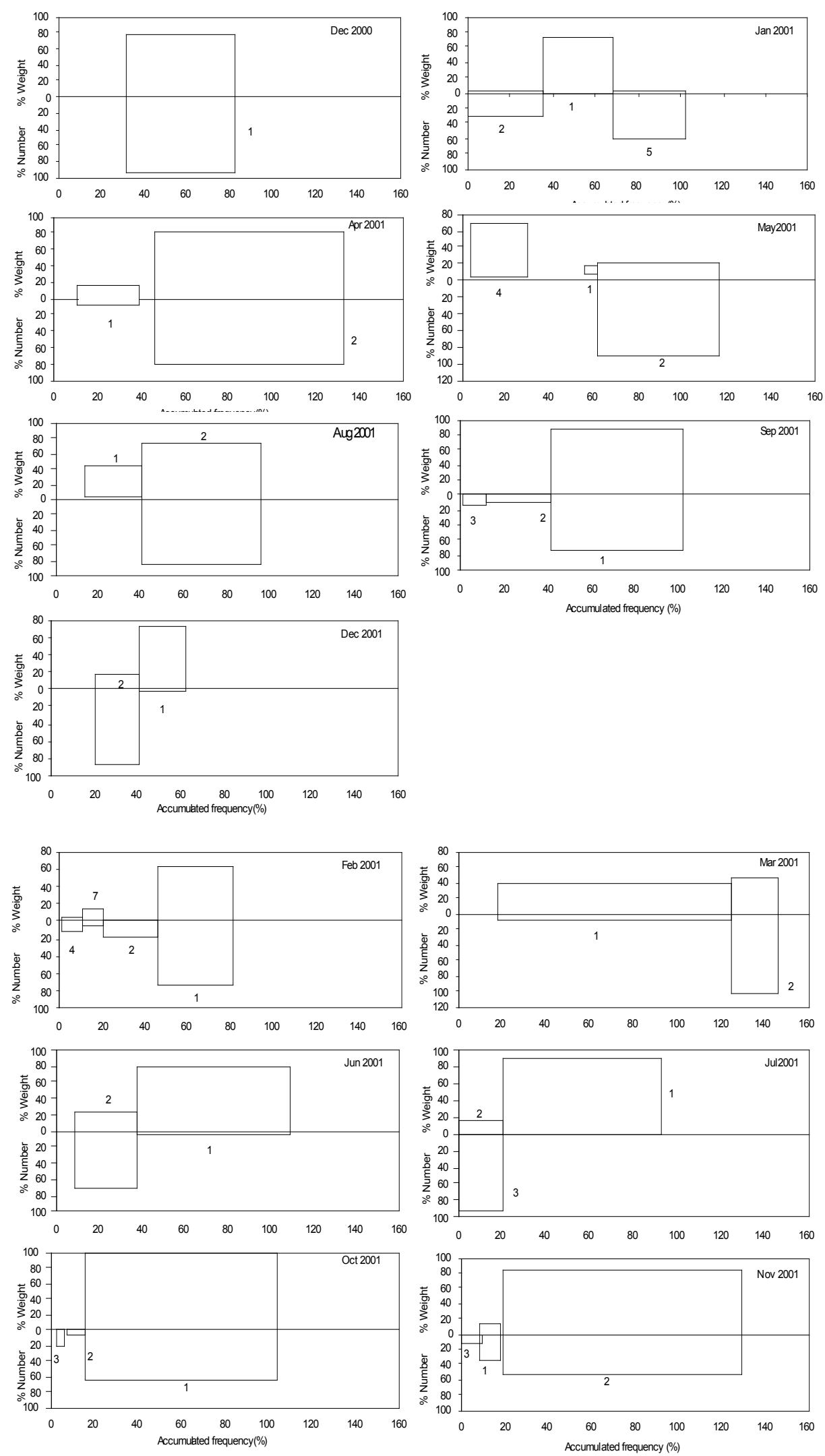

Fig. (4). Monthly IRI $I_{W}$. Average numbers: 1 Fish, 2 Crustaceans, 3 Crustacean larvae, 4 Mollusks, 5 Cnidarians, 6 Chaetognata, 7 Organic matter, in the diet of C. caballus.

finally, in May the dominant group was of cnidarians (43.3\%) (Fig. 4).
The Index of Relative Importance in volume (IRIV) was higher for the group of fish during the same months as IRI $\mathrm{I}_{\mathrm{W}}$; 
for crustaceans also the same months as $\mathrm{IRI}_{\mathrm{W}}$ were important and for mollusks only May stood out (Fig. 5).
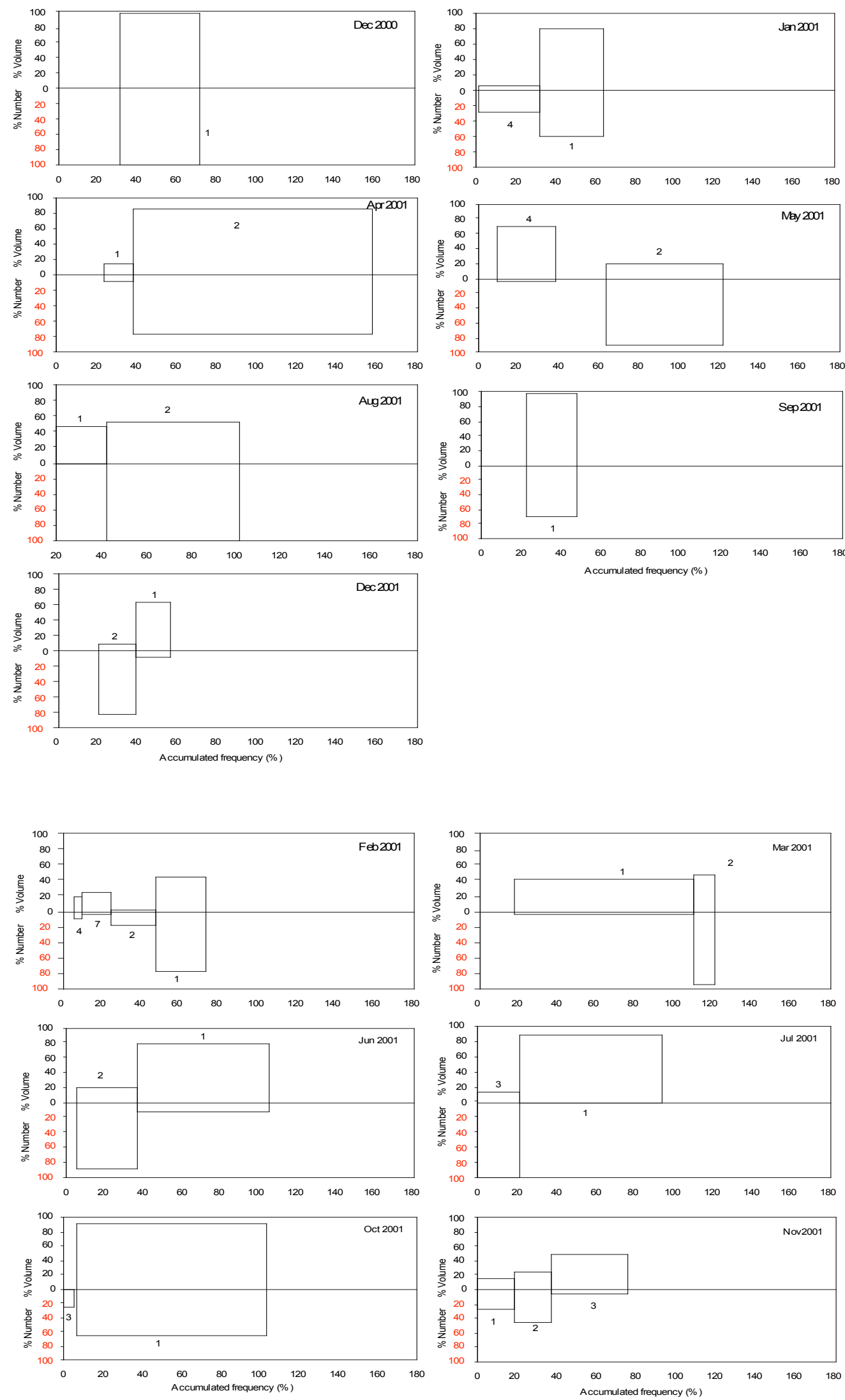

Fig. (5). Monthly IRI $I_{V}$. Average numbers: 1 Fish, 2 Crustaceans, 3 Crustacean larvae, 4 Mollusks, 5 Cnidarians, 6 Chaetognata, 7 Organic matter, in the diet of C. caballus. 


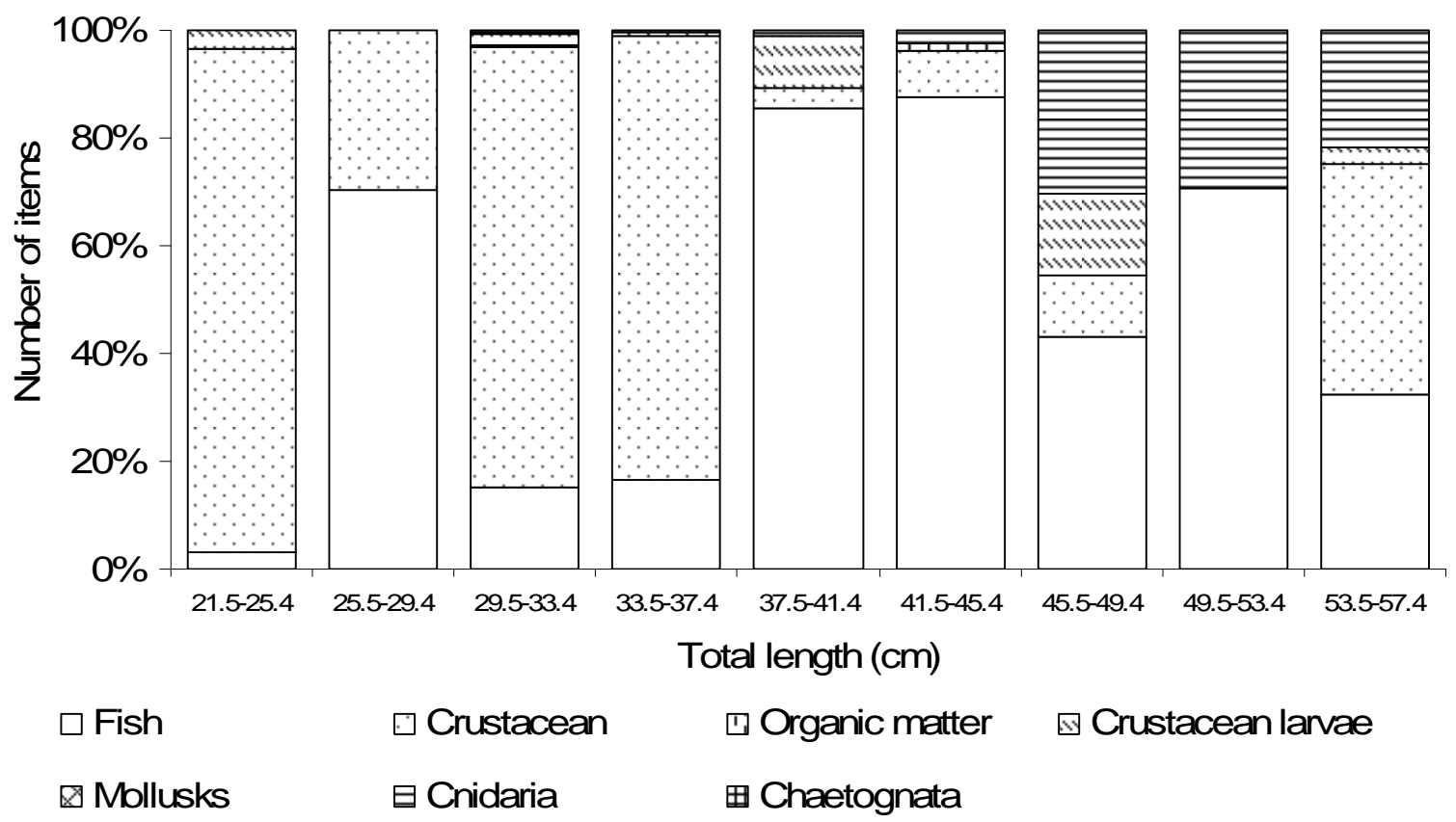

Fig. (6). Numeric index $(\% \mathrm{~N})$ for different lengths and prey groups of Caranx caballus.

individuals $(21.5-25.4 \mathrm{~cm}$ and $29.5-33.4 \mathrm{~cm})$ fed mainly on crustaceans and the main food of those measuring 25.5 to $29.4 \mathrm{~cm}$ were fish. Medium sized organisms fed mainly on crustaceans $(82.45 \%)$ and on fish. Larger organisms fed mainly on fish and those measuring 53.5 to $57.4 \mathrm{~cm}$, included other items like cnidarians, larvae and crustacean adults (Fig. 6).

Nevertheless the gravimetric index showed that small individuals $(21.5-33.4 \mathrm{~cm}$ and 25.5 to $29.4 \mathrm{~cm})$ fed mainly on fish. Individuals measuring 29.5 to $33.4 \mathrm{~cm}$ showed preference for crustaceans and fish. Medium sized specimens $(33.5-45.4 \mathrm{~cm})$ and larger individuals $(45.5-53.4 \mathrm{~cm})$ fed on fish mainly. Those measuring 53.5 to $57.4 \mathrm{~cm}$, showed a preference for crustaceans and cnidarians (Fig. 7). As they grow their diet is more varied.

Results of the volumetric index showed similar trends as the percentage by weight: a preference for fish in all sized individuals, although those from 21.5 to $25.4 \mathrm{~cm}$ and 53.5 to

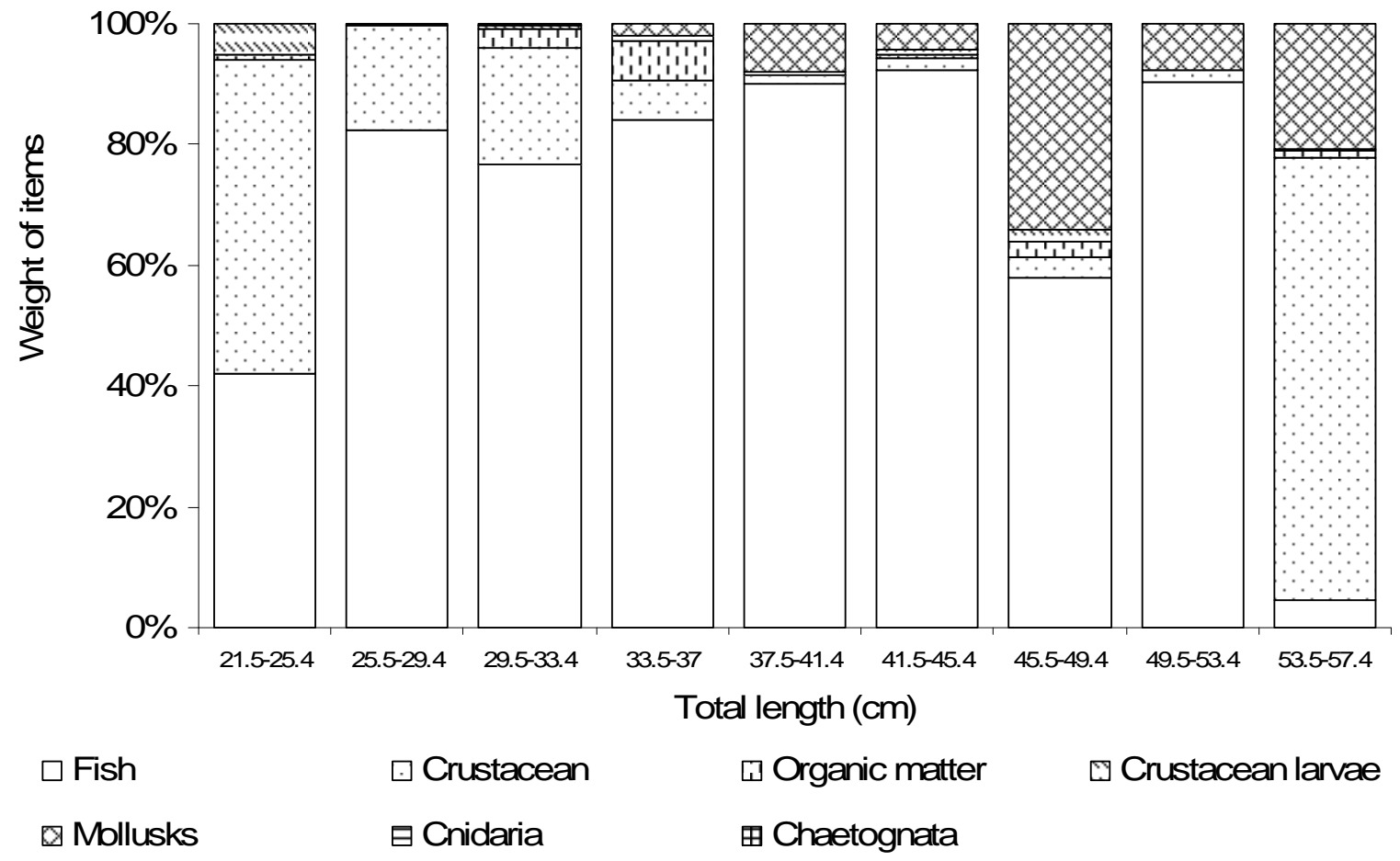

Fig. (7). Gravimetric index (\%W) for different lengths and prey groups of Caranx caballus, during one year. 


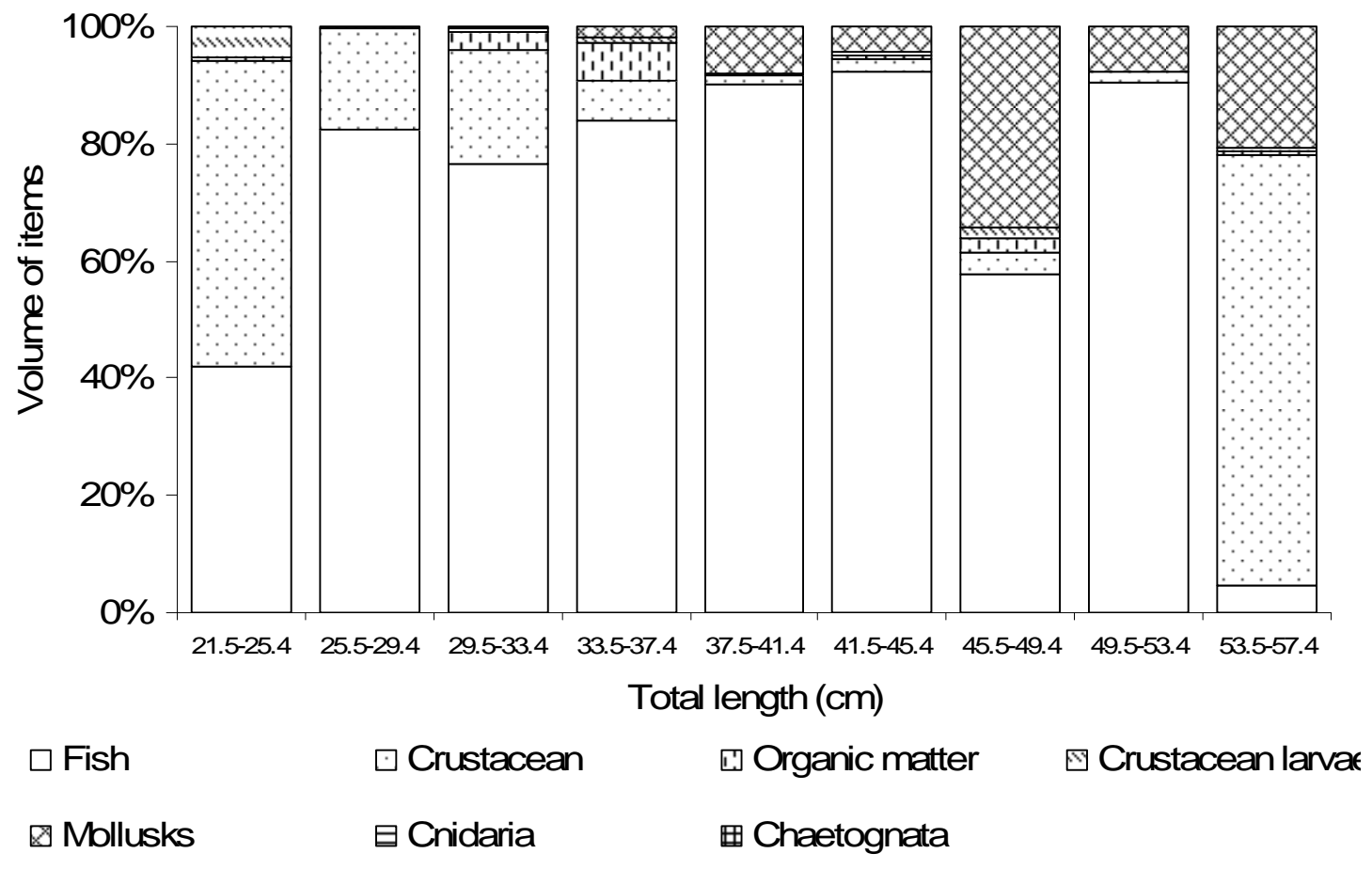

Fig. (8). Volumetric index $(\% \mathrm{~V})$ for different lengths and prey groups of Caranx caballus, during one year.

$57.4 \mathrm{~cm}$ showed preference for crustaceans. These last ones also consumed cnidarians in smaller proportion (Fig. 8).

The diet of males and females were very similar in the percentage in number of individuals, where crustaceans were dominant preys $(88.36 \%$ in males and $84.94 \%$ in females). As percentage by weight of individuals, the most abundant prey was fish $(61.16 \%$ in males and $79.21 \%$ in females $)$. The percentage by volume showed preference towards fish (males 60.04\% and females 76.60\%). Finally, \%IRI showed that the group of fish and crustaceans are very important in the diet (Fig. 9).

The diversity of the diet spectrum, also considered as the trophic amplitude niche showed different degrees of specialization in the feeding habits throughout the year, lower than 0.05 in the percentage of number, weight and volume (Table 2).

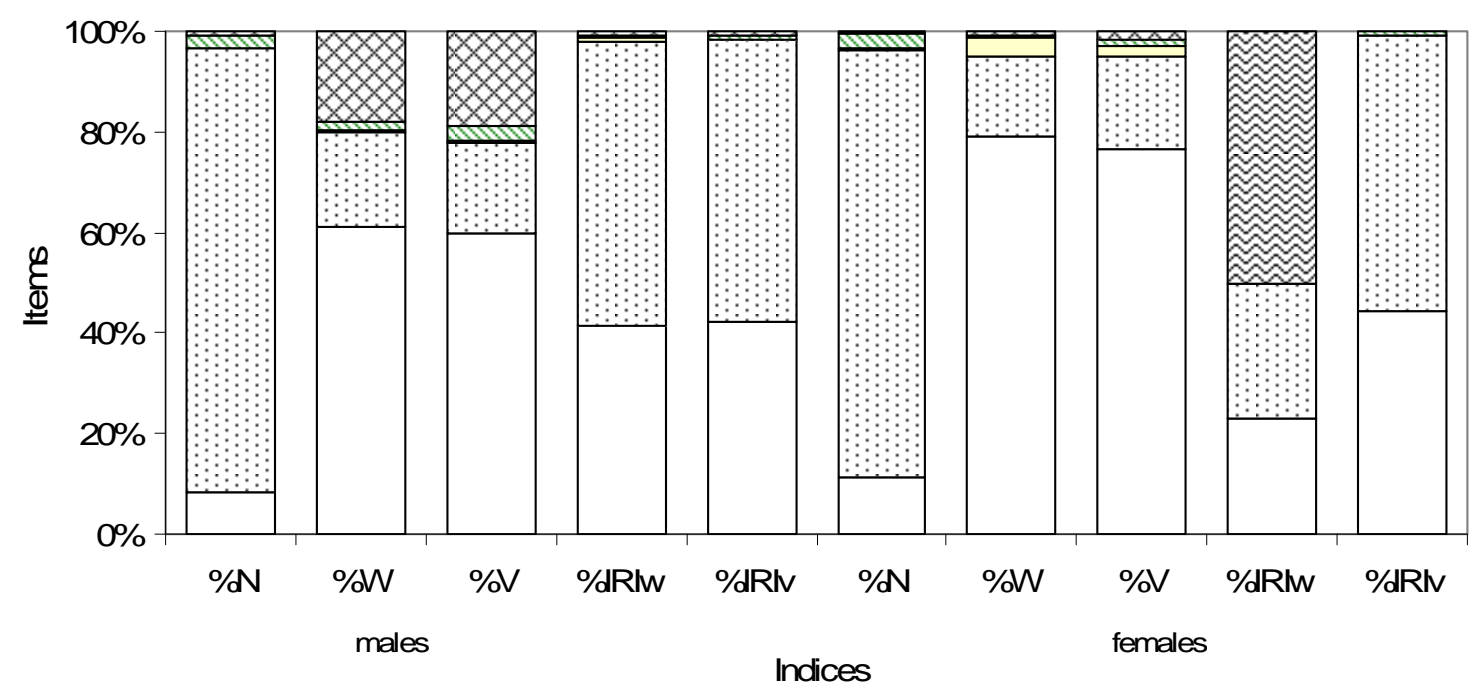

\begin{tabular}{|c|c|c|c|}
\hline$\square$ Fish & G Crustacean & $\square$ Organic matter & $\otimes$ Crustacean larvae \\
\hline Cnidaria & ○ Mollusks & * Chaetognata & \\
\hline
\end{tabular}

Fig. (9). Numeric index $(\% \mathrm{~N})$, gravimetric index $(\% \mathrm{~W})$, volumetric index $(\% \mathrm{~V})$, index of relative importance $(\% \mathrm{IRI})$ used for males and females of Caranx caballus and their prey groups during one year. 
Table 2. Monthly Sample Trophic Diversity According to Number, Weight and Volume of the Prey of Caranx caballus

\begin{tabular}{|c|c|c|c|}
\hline Months & Number & Weight & Volume \\
\hline \hline December (2000) & 0.00 & 0.03 & 0.05 \\
\hline January & 0.02 & 0.01 & 0.01 \\
\hline February & 0.02 & 0.07 & 0.09 \\
\hline March & 0.00 & 0.09 & 0.08 \\
\hline April & 0.02 & 0.08 & 0.10 \\
\hline May & 0.02 & 0.03 & 0.03 \\
\hline June & 0.01 & 0.03 & 0.04 \\
\hline July & 0.00 & 0.01 & 0.01 \\
\hline August & 0.02 & 0.12 & 0.10 \\
\hline September & 0.05 & 0.02 & 0.02 \\
\hline October & 0.03 & 0.02 & 0.04 \\
\hline November & 0.05 & 0.09 & 0.09 \\
\hline December (2001) & 0.00 & 0.06 & 0.05 \\
\hline
\end{tabular}

Results of the Alimentary Index (AI) showed that fish is the preferred item of the diet in the seven groups of lengths, with percentage of volume $(55.10 \%)$ and of weight $(58.81 \%)$. Crustaceans were frequent food with $11.25 \%$ and $10.78 \%$ respectively. The rest of the groups are accidental food, with a percentage smaller than $10 \%$ (Table 3 ), that is, an item that wasn't searched for.

Table 3. Alimentary Index (AI) of the Prey of Caranx caballus, According to the Percentage of Volume and Weight

\begin{tabular}{|c|c|c|}
\hline Groups & \% Volume & \% Weight \\
\hline \hline Fishes & 84.60 & 84.27 \\
\hline Crustacea & 13.93 & 14.32 \\
\hline Crustacean larvae & 0.36 & 0.22 \\
\hline Mollusca & 0.76 & 0.69 \\
\hline Cnidaria & 0.00 & 0.00 \\
\hline Chaetognatha & $2.56 \times 10^{-6}$ & 0.00 \\
\hline Organic mater & 0.35 & 0.51 \\
\hline
\end{tabular}

\section{DISCUSSION}

Feeding spectrum of C. caballus in the coast of Colima includes 42 prey types, which is a larger number compared with other carangids studied in Brazil [27], in India [28], in the Mediterranean [29] and in Colombia [7]. In contrast in Florida, Louisiana and Texas, Soloman \& Naughton [6] reported more than 150 different preys. Other authors [30] suggest the diet is a result or describes the species habitat, and the diversity of the prey can infer competition and overlap in diets of the species in the area.
The preys identified belong to five taxonomic groups: fishes (important in weight throughout the annual cycle and weight by the individuals' length), crustaceans (important in number for the annual cycle); mollusks, cnidarians and chaetognaths, present in some seasons. We separated two extra groups for the analysis: "Crustacean larvae" and "Organic matter" because they give more information as a separate item.

Apparently the difference in the diets of C. caballus and others are related to the variation abundance and availability of the prey. Soloman \& Naughton [6] reported for Florida, Louisiana and Texas, 28 families and 50 species of fish emphasizing that clupeids are most consumed and species of the families Engraulidae, Clupeidae and euphausids predominated in stomach contents of C. caballus.

The prey preference of $C$. caballus does not differ much from other carangids being basically fishes. Engraulids were described as a family of fish present in the stomachs of Oligoplites saurus and C. caballus [6]. They also reported the presence of zoea and megalops in their stomachs, and differ in the hymenopteran and dipteran insects. Crustaceans and mollusks were also reported, but differ in the presence of insects and insect larvae in their diet [27], probably owing to the differences in the influence of coastal rivers and/or latitude. In his study, Santos-Martínez [31] agrees with this paper, according to the percentage in number, weight and volume of prey, with the feeding spectrum where fish, crustaceans and insects are present. Differences found in the feeding throughout the year are due to changes of natural occurrence of prey in the sampling area, whereas along years there are no changes. On the other hand, nutritional habits can change in a same species depending of the locality [32], feeding conditions, availability and seasonality of sex. This variation was reported for other species of the same family, such as Caranx hippos [5] and C. ruber [33]. Similarities in the feeding at different sizes of $O$. saurus and $O$. palometa were also found $[7,29]$.

Results of this study show that the variation between the analyses of IRI elaborated with weight and volume is minimum; they only vary in small feeding items. Without doubt the preference, by far, is for fishes, followed by crustaceans and mollusks in smaller proportions. Smaller organisms tended to feed more on fishes, perhaps because it offers better quality of protein, very important in young specimens, to grow faster and avoid being a prey themselves.

The diversity of the diet spectrum or amplitude of the trophic niche of $C$. caballus showed that it is specialized, with preference for fish throughout the year, in all its lengths and in both males and females. It was also found that there were other organisms as supplement of a basic diet.

C. caballus has a defined alimentary index reported in other studies of Carangidae family, whose diet is similar; its preferential food is fish, frequently crustaceans and occasionally crustacean larvae, mollusks, cnidarians, chaetognaths and organic matter, which vary in other carangids according to the study area.

\section{CONFLICT OF INTEREST}

None declared. 


\section{ACKNOWLEDGEMENT}

None declared.

\section{REFERENCES}

[1] Espino-Barr E, Gallardo-Cabello M, Cabral-Solís EG, Garcia-Boa A, Puente-Gómez M 2004. Aspectos biológico pesqueros del jurel Caranx caninus Günther, 1868 y del cocinero Caranx caballus Günther, en la costa de Colima. INP, CRIP-Manzanillo, Informe de Investigación 1868; p. 37.

[2] Allen GR, Robertson DR. Fishes of the tropical Eastern Pacific. Honolulu: University of Hawaii Press 1994.

[3] Fischer W, Krupp F, Schneider W, Sommer C, Carpenter KE, Niem VH. Guía FAO para la identificación de especies para los fines de la pesca. Pacífico Centro-Oriental. Vol. 3. FAO, Roma 1995.

[4] Sierra LM, Claro R, Popova OA. Trophic ecology of the marine fishes of Cuba. In: Claro R, Lindeman KC, Parenti LR, Eds. Ecology of the marine fishes of Cuba, Washinton, D.C. \& London: Smithsonian Institute Press 2001; pp. 115-48.

[5] Sierra LM, Claro R, Popova OA. Alimentación y relaciones tróficas. In: Claro R, Ed. Ecología de los peces marinos de Cuba. Instituto de Oceanología Academia de Ciencias de Cuba y Centro de Investigaciones de Quintana Roo, México 1994; pp. 263-320.

[6] Saloman CH, Naughton SP. Food of crevalle jack (Caranx hippos) from Florida, Louisiana and Texas. NOAA Technologie Memoir, NMFS-SEFC-134, 1984.

[7] Duque-Nivia G, Acero A, Santos-Martínez P, Rubio ER. Food habits of the genus Oligoplites (Carangidae) from the Cienega Grande de Santa Marta-Colombian Caribbean. Cybium 1996; 20(3): 251-60

[8] Eschmeyer WN, Herald ES, Hammann H. A field guide to Pacific coast fishes of North America. The Peterson Field Guide Series. Boston: Houghton Mifflin Company 1983.

[9] Smith-Vaniz WF. Carangidae. In: Fischer W, F Krupp, W Schneider, C Sommer, KE Carpenter VH Niem, Eds. Guía FAO para la identificación de especies para los fines de la pesca. Roma: Pacífico Centro-Oriental FAO, 1995; 2: 940-86.

[10] Macías R, Santana H, Valdez JJ. Informe final del Proyecto Prospección Hidroacústica en el litoral del estado de Colima. SEPESCA/IPN, CRIP-Manzanillo, Colima, 1985.

[11] Rathbun MJ. The cancroid crabs of America of the families Eurylidae, Portunidae, Atelecyclidae, Cangridae and Xanthidae. Bull US Natl Mus 1930; 152: 1-229.

[12] Brusca RC. Common Intertidal Invertebrates of the Gulf of California. Tucson: University of Arizona Press 1980.

[13] Hendrickx ME, Salgado-Barragán J. Estomatópodos (Crustacea: Hoplocarida) del Pacífico Mexicano. Instituto de Ciencias del Mar y Limnología, Universidad Nacional Autónoma de México, Publicaciones Especiales 1991; 20: 1-200.

[14] Hendrickx ME. Camarones. In: Fischer W, Krupp F, Schneider W, Sommer C, Carpenter KE, Niem VH, Eds. Guía FAO para la identificación de especies para los fines de la pesca. Pacífico Centro-Oriental FAO, Roma 1995a; 1: 417-528.

[15] Hendrickx ME. Camarones. In: Fischer W, Krupp F, Schneider W, Sommer C, Carpenter KE, Niem VH, Eds. Guía FAO para la identificación de especies para los fines de la pesca. Roma: Pacífico Centro-Oriental FAO 1995b; 1: 565-630.

[16] Pérez-Farfante I, Kensley B. Penaeoid and Sergestotoid shrimps and prawns of the world. Keys and diagnoses for the families and genera. Mémoirs du Muséum Nationalle d'Histoire Naturelle 1997; 175: 1-23.

[17] Thomson DA, Findley JT, Kerstitch AN. Reef fishes of the sea of Cortez. The rocky-shore fishes of the Gulf of California. New York: John Wiley and Sons 1979.

[18] Newell GE, Newell RC. Marine plankton: a practical guide. London: Hutchinson Press 1979.

[19] Moser HG, Ed. The early stages of fishes in the California Current Region, CalCOFI Atlas 1996; 33: 1-1505.

[20] Pinkas L, Oliphant MS, Iverson LK. Food habitats of albacore, bluefin tuna, and bonito in California waters. California Department of Fish and Game. Fish Bull 1971; 152: 1-105.

[21] Rosecchi E, Nouaze Y. Comparaison de cinq indices alimentaires utilisés dans l'analyse des contenus stomacaux. Revue des Travaux de l'Institut des Peches Maritimes 1987; 49(3/4): 111-23.

[22] Caillet MG, Love MS, Ebeling AW. Fishes. A field and laboratory manual on their structure identification and natural history. Belmount: Wads Worth Publishing 1986.

[23] Daniel WW. Bioestadística. Base para el análisis de las ciencias de la salud. México: Noriega-Limusa 1997

[24] Levins R. Evolution in changing environments: some theoretical explorations. Princeton: Princeton University Press 1968.

[25] Hespenheide HA. Ecología de los productores primarios en la Laguna de Celestún, México. Patrones de variación espacial y temporal. Tesis de Doctorado, Universidad de Barcelona, Barcelona 1975

[26] Lauzanne L. Régimes alimentaires d'Hydorcyon forsaalii (Pisces, Characidae) dans le lac Tchad et ses tributaires. Cahiers ORSTROM, Série Hydrobiologica 1975; 9(2): 105-121.

[27] Monteiro-Neto C, Rodrigues-Cunha LP. Seasonal and ontogenetic variation in food habits of juvenile Trachinotus marginatus Cuvier, 1832 (Teleostei, Carangidae) in the surf zone of Casino Beach. RS Brazil. Atlántica, Rio Grande 1990; 12(1): 45-54.

[28] Roux O, Conand F. Feeding habits of the bigeye scad, Selar crumenophthalmus (Carangidae) in La Réunion Island waters (South-Western Indian Ocean). Cybium 2000; 24(2): 173-9.

[29] Matallanas J, Casadevall M, Carrassón M, Boix J, Fernández V. The food of Seriola dumerili (Pisces: Carangidae) in the Catalan Sea (Western Mediterranean). J Mar Biol Assoc UK 1995; 75: 257 60 .

[30] Sudekum AE, Parrish JD, Radke RL, Ralston S. Life history and ecology of large jacks in undisturbed, shallow, oceanic communities. Fish Bull 1991; 89: 493-513.

[31] Santos-Martínez A. Estudio biológico y ecológico de la ictiofauna de la Ciénaga Grande de Santa Marta, Caribe Colombiano. Tesis de Maestría, Universidad Nacional de Colombia, Bogotá 1989.

[32] Prejs A, Colomine G. Método para el estudio de los alimentos y las relaciones tróficas de los peces. Universidad Central de Venezuela y Universidad Varsovia, Polonia 1981 p. 127.

[33] Sierra LM, Popova OA. Particularidades de la alimentación del civil (Caranx ruber Bloch) en la región suroccidental de la plataforma cubana. Reporte de Investigación del Instituto de Oceanología 1982; 3: 19 . 